\title{
Epigarcinol and isogarcinol isolated from the root of Garcinia ovalifolia induce apoptosis of human promyelocytic leukemia (HL-60 cells)
}

\author{
Constant Anatole Pieme ${ }^{1,2^{*}}$, Pathaleon Ambassa ${ }^{2,3}$, Emmanuel Yankep $^{3}$ and Ajit Kumar Saxena ${ }^{2^{*}}$
}

\begin{abstract}
Background: Plants from garcinia genus have been used for centuries against several diseases.

Objective: This study aimed to investigate the mechanism of apoptosis induced by epigarcinol and isogarcinol isolated from the root of Garcinia ovalifolia (Clusiaceae) on human promyelocytic leukemia (HL-60 cells).

Methods: Epigarcinol and isogarcinol were isolated from the root of $G$. ovalifolia by using column chromatography method. The antiproliferative property of these molecules and fractions were assessed with 3-(4, 5-dimethylthiazol2-yl)-2, 5-diphenyltetrazolium bromide (MTT) assay. The light fluorescence microscope was utilized to observe the morphological changes of HL-60 cells after $24 \mathrm{~h}$ treatment. Early apoptosis and cell cycle distribution were analyzed by using flow cytometry (FCM).
\end{abstract}

Results: The results showed that epigarcinol and isogarcinol inhibited the proliferation of HL-60 and PC-3 cells in a concentration-dependent manner with $\mathrm{IC}_{50}$ varying between 4 and $76 \mu \mathrm{g} / \mathrm{mL}$ depending on the cell line and the molecule. The apoptosis rate and the number of apoptotic cells significantly increased with the augmentation of the concentration of the molecules. The results of flow cytometry (FCM) indicated that epigarcinol and isogarcinol induced significant $\mathrm{G}_{2} / \mathrm{S}$ arrest of $\mathrm{HL}-60$ cells, the disruption of mitochondrial membrane potential and reactive oxygen species (ROS) generation.

Conclusion: These results indicated that epigarcinol and isogarcinol demonstrated in vitro antiproliferative properties and induce apoptosis of $\mathrm{HL}-60$ cells which is related to the $\mathrm{G}_{2} / \mathrm{S}$ arrest, and it exerts its apoptotic effect through the loosing of mitochondrial membrane potential.

Keywords: Apoptosis, Cytotoxicity, 7-epigarcinol, Isogarcinol, Antiproliferative, Garcinia ovalifolia

\section{Background}

The global burden of cancer continues to increase largely because of the aging and growth of the world population alongside an increasing adoption of cancer-causing behaviors in economically developing countries. Based on the GLOBOCAN 2012 estimations, about 14.1 million cancer cases and 8.2 million cancer deaths are recorded

\footnotetext{
*Correspondence: apieme@yahoo.fr; aksaxena@iiim.ac.in

${ }^{2}$ Cancer Pharmacology Division, Indian Institute of Integrative Medicine,

180001, Canal Road, Jammu, India

Full list of author information is available at the end of the article
}

in 2012. More than half of all cancers (56.8 \%) and cancer deaths $(64.9 \%)$ in 2012 occurred in less developed regions of the world, and these proportions will increase further by 2025 [1]. Given the fact that the incidence rate of cancer disease is continuously increasing in Africa, a number of effective prevention measures have been introduced in order to substantially reduce the incidence and the mortality. Of all the efforts that have been made, the search for new anticancer compounds in foods or plant medicines is a realistic and promising approach to the prevention and the treatment of cancer [2]. Natural products, including plants, microorganisms and marines, 
have been considered as valuable sources for anticancer drug discovery [3].With the high speed advances in biomedical research, there has been a growing interest in screening natural products for their potential use in disease prevention and treatment. These natural substances are of interest, as they are potential sources of anticancer compounds with minimal debilitating toxicity and side effects [4]. Because of the different components, herbs and plants may have synergistic activities or buffering toxic effects, mixtures or extracts of herbs might have more therapeutic or preventive activity than alone [5, 6]. Several chemopreventive properties have long been attributed to polyphenolic compounds present in the human diet. One remarkable compound in this list is resveratrol, which possesses a wide range of pharmacological properties, including antiinflammatory, antioxidant, and antiplatelet effects and has been proposed as a cancer chemotherapeutic agent $[7,8]$.

Garcinia ovalifolia (G. ovalifolia) which belongs to Clusiaceae family is growing in lowland forests tropical of Africa, Asia, America and Australia [9]. G. ovalifolia is a tree of 10-15 m high, with yellow sticky latex, generally distributed in fringing forests and riverbanks in West and central Africa [10]. The genus Garcinia includes some 200 species found in the tropics, especially Asia and Africa. Plants from Garcinia genus demonstrated several pharmacological proprieties including anti-HIV $[10,11]$, antioxidant, antibacterial [12], cytotoxic [11, 12], anticancer and antimalarial [13]. The literature review shows that G. ovalifolia contains several molecules among which, isoxanthochimol [12, 14], endodesmiadol, canophyllol, canophyllal [12, 15], gallic acid, garcinane [16], 3-methylcheffouxanthone, two new friedelane triterpene derivatives ovalifolone A and B [12]. Epi-garcinol, iso-garcinol and manniflavanone isolated from our plant (G. ovalifolia) have also been discovered in other plants extract such as Garcinia preussii [17] Hypericum lanceolatum [18] Moronobea coccinea [19] Symphonia globulifera [20] and Garcinia bancana [21]. Several biological properties of epi-garcinol, iso-garcinol and manniflavanone have been investigated which included antiplasmodial [20$23]$, antibacterial $[17,18]$ and immunosuppressant effects [24].Several biological properties of these molecules have been investigated such as antibacterial, cytotoxicity activity on Artemia salina [13] and anti-HIV [25]. However, G. ovalifolia has not been studied for its anticancer effects. Therefore, we attempted to investigate the growth-inhibitory and apoptotic effects of G. ovalifolia extract and fractions against human cancer cells (HL-60 cells and PC-3).

\section{Methods}

\section{Collection of plant material}

The Stem bark of Garcinia ovalifolia (Clusiaceae), was collected in Makenene (Centre region of Cameroon) in December 2010 and identified by Victor NANA of the National Herbarium Cameroon and a sample specimen is deposited on the voucher no. 20854/SRFCam.

\section{Extraction and isolation of compounds}

Air-dried and powdered stem bark of $G$. ovalifolia $(2.5 \mathrm{~kg})$ were macerated in methanol $(5 \mathrm{~L})$ for $48 \mathrm{~h}$ at room temperature. The solution obtained was then filtered through Whatman No. 1 filter paper. The filtrate solution was concentrated under vacuum into a paste to give a dark brown crude extract (150 g). The slurry was made of crude extract (100 g) by dissolving in $\mathrm{MeOH}$, adsorbed on $120 \mathrm{~g}$ of silica gel (60-120 mesh) which was subjected to Vacuum Liquid Chromatography (VLC) column packed with $800 \mathrm{~g}$ of silica gel (120-200 mesh). Elution was carried out using using hexane/ethyl acetate and ethyl acetate/methanol gradients as eluents at a flow rate of $2 \mathrm{~mL} / \mathrm{min}$. Fractions ( $250 \mathrm{~mL}$ each) were collected as follows: pure hexane (fractions 1-5), hexane/ethyl acetate 75/25 (fractions 6-12), hexane/ethyl acetate 50/50 (fractions 13-25), ethyl acetate (fractions 26-33), acetate/ methanol 90/10 (fractions 116-125) and methanol (fractions 126-132). These fractions were pooled on the basis of the thin layer chromatography analysis on seven subfractions from A to $G$ respectively.

Further chemical investigation of sub- fractions $B, C$ and D was carried out using column chromatography, preparative tin layer chromatography and recrystallization in different solvent yielded three compounds: 7-epigarcinol (250 $\mathrm{mg})$; isogarcinol $(25 \mathrm{mg})$ manniflavanone (40 mg) respectively. All these structures were obtained by the means of spectroscopic analysis including $1 \mathrm{D}$ and 2D NMR and mass spectra.

\section{Cell culture}

Human promyelocytic leukemia (HL-60 cells) and prostate cancer (PC-3 cells) were obtained from European Collection of Cells Culture (ECCC), Sigma-Aldrich, India. They were grown in RPMI-1640 medium containing $10 \%$ Fetal bovine serum (FBS),penicillin (100 IU/ $\mathrm{mL})$ and streptomycin $(100 \mu \mathrm{g} / \mathrm{mL}$ medium $)$.The cells suspension was kept in the incubator (Thermocom Electron Corporation, USA) at $37{ }^{\circ} \mathrm{C}, 5 \% \mathrm{CO}_{2} ; 98 \%$ humidity. Cells were used for different assays during logarithmic growth phase while the untreated control cultures received only the vehicle (DMSO $<0.1 \%$ ). 


\section{Cells viability and treatments}

The human promyelocytic leukemia (HL-60 cells) and prostate cancer (PC-3 cells) were seeded in 96 different well plates containing $15 \times 103$ and $6 \times 103$ cells $/ 100 \mu \mathrm{L} /$ well, respectively. The cultured cells were then treated (triplicate wells per condition) by adding $100 \mu \mathrm{L}$ of serial dilutions of the three molecules (7-epigarcinol, isogarcinol and manniflavanone) in DMSO to give a final concentration of $100,30,10$ and $1 \mu \mathrm{g} / \mathrm{mL}$. The HL-60 treated cells were incubated immediately while for PC-3 cells, the molecules were added after $24 \mathrm{~h}$ of incubation. In addition, the DMSO alone was added to another set of cells as the solvent control (DMSO $<0.1 \%$ ). The cells were then incubated for another $48 \mathrm{~h}$ prior to the addition of $20 \mu \mathrm{L}$ of $2.5 \mathrm{mg} / \mathrm{mL}$ solution of 3-(4, 5-dimethylthiazol2-yl)-2, 5-diphenyltetrazolium bromide (MTT) into each well. The incubation was continued for $3 \mathrm{~h}$ before the media was removed. A mixture of DMSO $(150 \mu \mathrm{L})$ was added to each well and mixed to ensure dissolving of the crystal formazan before the absorbance at $570 \mathrm{~nm}$ was measured. Three replications of each experiment were performed and fifty percent of inhibitory concentration $\left(\mathrm{IC}_{50}\right)$ of each extract was calculated.

\section{DNA content and cell cycle phase distribution}

HL-60 cells $\left(1 \times 10^{6}\right.$ cells $/ 2 \mathrm{~mL} /$ well $)$ were treated with molecules at $20,50,100 \mu \mathrm{g} / \mathrm{mL}$ for $24 \mathrm{~h}$. They were harvested and washed with $1 \mathrm{~mL}$ of PBS, then centrifuged at $400 \mathrm{~g}$ for $5 \mathrm{~min}$ at $4{ }^{\circ} \mathrm{C}$. The pellet was suspended in $100 \mu \mathrm{L}$ of PBS and $900 \mu \mathrm{L}$ of hypertonic citrate buffer (PI-25 $\mu \mathrm{g} /$ $\mathrm{mL}$, RNAase- $40 \mu \mathrm{g} / \mathrm{mL}$, sodium citrate- $0.1 \%$ and Triton$100 \mathrm{X}-0.03 \%$ ) and incubated at $37{ }^{\circ} \mathrm{C}$ in dark for $20 \mathrm{~min}$. Finally, cells were analyzed immediately on flow cytometer FACS Calibur (Becton-Dickinson, USA). The data were collected in list mode on 10,000 events and illustrated in a histogram, where the number of cells (counts) is plotted against the relative fluorescence intensity of PI (FL-2; 入em: $585 \mathrm{~nm}$; red fluorescence). The resulting DNA distributions were analyzed by Modfit (Verity Software House Inc., Topsham, ME) for the proportions of cells in $G_{0}-G_{1}, S$ - phase, and $G_{2}-M$ phases of the cell cycle [26].

\section{Hoechst 33258 staining of cells for nuclear morphology}

HL-60 cells $\left(2 \times 10^{6}\right.$ cells $/ 3 \mathrm{~mL} /$ well $)$ were treated with isogarcinol and 7-epigarcinol at different concentrations of extract for $24 \mathrm{~h}$. They were collected, centrifuged at $400 \mathrm{~g}$ and washed once with PBS. A solution of Hoechst (Hoechst, $10 \mu \mathrm{g} / \mathrm{mL}$; citric $10 \mathrm{mM} ; \mathrm{Na}_{2} \mathrm{HPO}_{4} 0.45 \mathrm{M}$; Tween-20 $0.05 \%$ ) was added in each tube and kept in the dark at room temperature for $30 \mathrm{~min}$. The mixture was washed with PBS and the pellet suspended in $100 \mu \mathrm{L}$ of PBS/glycerol (1:1). The solution $(10 \mu \mathrm{L})$ was poured into the slide and nuclear morphology alterations observed under fluorescence microscope (Olympus $\times 70$, magnification $\times 20$ ) [26].

\section{Mitochondrial membrane potential (MMP) assay}

HL-60 cells $\left(1 \times 10^{6}\right.$ cells $/ 2 \mathrm{~mL} /$ well $)$ were treated with isogarcinol and 7-epigarcinol at different concentrations for $24 \mathrm{~h}$. Thirty minutes before the end of the experiment, the cell culture was treated with Rhodamine-123 (200 nM) and kept in the dark for $30 \mathrm{mn}$. Cells were collected, centrifuged (400 g; $4{ }^{\circ} \mathrm{C}$; $5 \mathrm{~min}$ ), the pellet was washed with $1 \mathrm{~mL}$ of PBS and centrifuged as mentioned earlier. The fluorescence intensity of 10,000 events was analyzed in FL-1 channel on BD FACSCalibur (Becton-Dickinson, USA) flow cytometer. The decrease in fluorescence intensity because of membrane mitochondrial potential loss was analyzed in FL-1 channel and the change of potential membrane $(\Delta \psi \mathrm{m})$ was assessed by comparing fluorescence.

\section{Reactive oxygen species (ROS) assay}

ROS production was monitored by flow cytometry using $2^{\prime}, 7^{\prime}$-dichlorodihydrofluorescin diacetate $\left(\mathrm{DCFH}_{2}-\mathrm{DA}\right)$. This dye is a stable non polar compound that readily diffuses into cells and is hydrolyzed by intracellular esterase to yield $2^{\prime}, 7^{\prime}$-dichlorodihydrofluorescin $\left(\mathrm{DCFH}_{2}\right)$, which is trapped within the cells. Hydrogen peroxide or low molecular weight peroxides produced by the cells oxidizes $\mathrm{DCFH}_{2}$ to a highly fluorescent compound $2^{\prime}, 7^{\prime}$-dichlorofluorescein (DCF). Thus, the fluorescence intensity was proportional to the amount of hydrogen peroxide produced by the cells. Briefly, HL-60 cells $\left(1 \times 10^{6}\right.$ cells $/ 2 \mathrm{~mL} /$ well $)$ were treated with isogarcinol and epigarcinol at different concentrations for $24 \mathrm{~h}$. Thirty minutes before the end of the experiment, the cell culture was treated with $\mathrm{DCFH}_{2}$-DA $(50 \mu \mathrm{M})$ and kept in the dark. Cells were then collected, centrifuged (200 g; $4{ }^{\circ} \mathrm{C}$; $5 \mathrm{~min}$ ) and the pellet was washed with $1 \mathrm{~mL}$ of PBS and centrifuged as mentioned earlier. The pellet was suspended in $500 \mu \mathrm{L}$ of PBS and the fluorescence was assessed by comparing two fluorescence emission $480 \mathrm{~nm} / 530 \mathrm{~nm}$ using a flow-cytometer (BD-LSR).

\section{Statistical analysis}

The viability experiments were done in triplicates and each data point represents the average of at least 3 independent experiments. For other assays, three independent experiments were made and one of them had been chosen as result to post in this study.

\section{Results}

\section{Cytotoxic effect of G. ovalifolia fractions on HL-60 and PC-3 cells}

To investigate the effect of $G$. ovalifolia fractions and extract on HL-60 and PC-3 cell proliferation, cells were 
treated with different concentrations for $48 \mathrm{~h}$. The cytotoxic effect of these fractions and extract G. ovalifolia on HL-60 and PC-3 cells was evaluated by MTT assay. As shown in Fig. 1, the addition of isogarcinol and epigarcinol to the cultured cells significantly inhibited the proliferation of these cells in a concentration-dependent manner (Fig. 1a, b).

The fifty percent inhibitory concentration $\left(\mathrm{IC}_{50}\right)$ after $48 \mathrm{~h}$ were 7,8 and $12 \mu \mathrm{g} / \mathrm{mL}$ for HL-60 cells respectively for epigarcinol; isogarcinol and unknow molecule while for PC-3 cells these value are 7, 4 and $76 \mu \mathrm{g} / \mathrm{mL}$ respectively for epigarcinol; isogarcinol and manniflavanone (Table 1). These results indicated that epigarcinol; isogarcinol isolated from G. ovalifolia effectively inhibited the proliferation of both HL-60 and PC-3 cells and the antiproliferative activity of HL-60 cells greater than that of PC-3 cells. These two molecules (epigarcinol and isogarcinol) were used to continue the study.

\section{Morphology changes of HL-60 cells}

To further confirm that cell apoptosis was induced by isogarcinol and epigarcinol from G. ovalifolia in HL-60 cells, a morphological examination was performed by Hoechst staining. As shown in Fig. 2, the nuclear Hoechst staining of the control cells was slightly blue and homogeneous, while cells treated with the two molecules exhibited morphological features of apoptotic cells, such as condensed chromatin with bright nuclear Hoechst staining. Under fluorescence microscope, the treated cell displayed an increase of cell damage and the level damage become higher when the concentration of the molecules is raised. Taken together, the obtained results indicate the
Table 1 Fifty percent inhibition of molecules isolated from G. ovalifolia

\begin{tabular}{lllll}
\hline Cell & \multicolumn{1}{l}{$\mathbf{C}_{\mathbf{5 0}}(\boldsymbol{\mu g} / \mathbf{m l})$} & & & \\
\cline { 2 - 5 } & Epigarcinol & Isogarcinol & Manniflavanone & Unknown \\
\hline PC-3 & $7 \pm 1.9$ & $8 \pm 2.6$ & $>100$ & $12 \pm 3.4$ \\
HL-60 & $7 \pm 1.3$ & $4 \pm 2.1$ & $76 \pm 2.3$ & $>100$ \\
\hline
\end{tabular}

Results are expressed as mean $\pm \mathrm{SD} ; \mathrm{n}=3$; Epi:7-epigarcinol; Iso: Isogarcinol; Man: manniflavanone; G: molecule with structure need to be elucidated

induction of apoptosis in HL-60 cells after $24 \mathrm{~h}$ treatment with isogarcinol and epigarcinol.

\section{Effect of $B$ and $C$ fractions on intracellular reactive oxygen species in $\mathrm{HL}-60$ cells}

The generation of intracellular ROS is always associated with MMP disruption and cell apoptosis. To investigate this association, we examined the levels of ROS in HL-60 cells treated with epigarcinol and isogarcinol. ROS was monitored by the oxidation-sensitive fluorescent dye $2^{\prime}, 7^{\prime}$-dichlorofluoresceindiacetate $\left(\mathrm{DCFH}_{2}\right.$-DA). A slight increase in DCF fluorescence was detected in the treated cells with both epigarcinol and isogarcinol (Fig. 3). A slight increase of fluorescence 4-6 times higher than the control was found after treatment of cells with isogarcinol $(10 \mu \mathrm{g} / \mathrm{mL}$; Fig. $3 \mathrm{~A})$ and epigarcinol $(5 \mu \mathrm{g} / \mathrm{mL}$; Fig. 3B). At the concentration of $20 \mu \mathrm{g} / \mathrm{mL}$, both epigarcinol and isogarcinol showed no ROS production this can be explained by the fact that at higher concentration, these two molecules act as antioxidant which neutralized and fixed ROS produced by the cells (Fig. 3C).
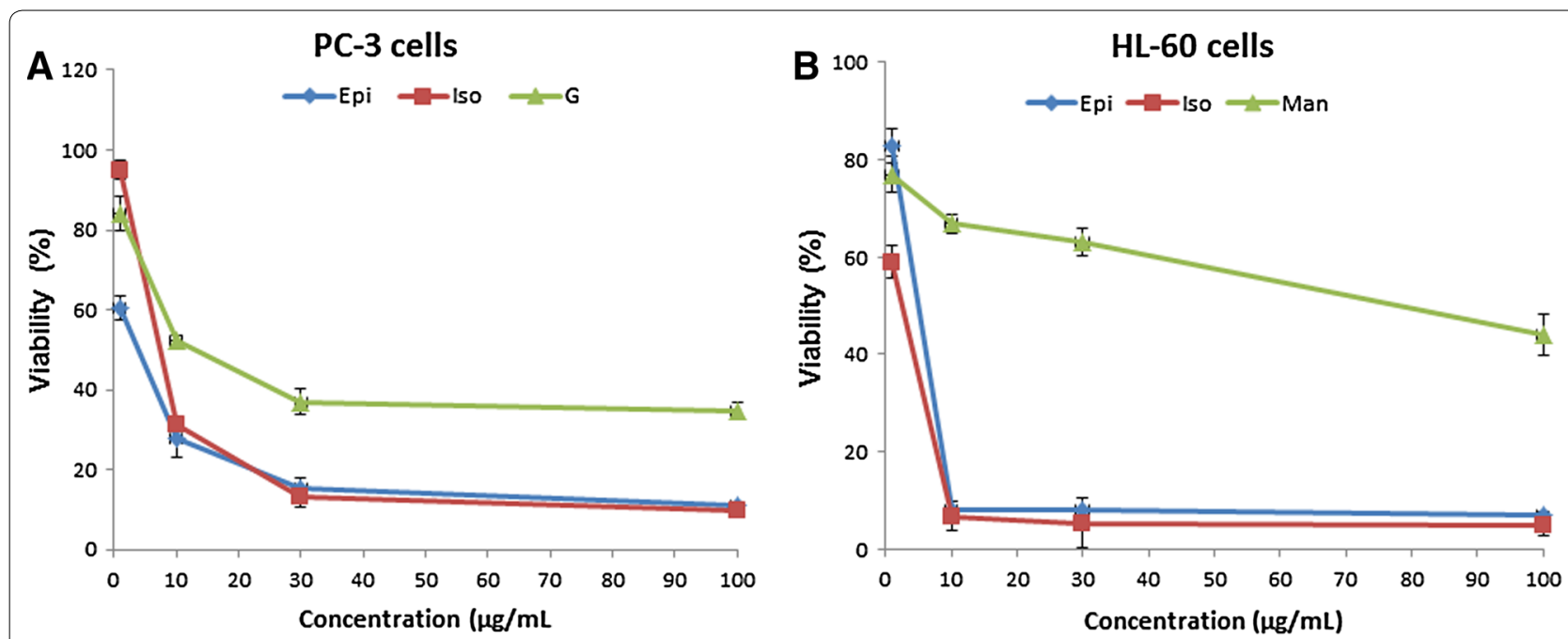

Fig. 1 Inhibitory effects and cytotoxicity of G. ovalifolia extracts. PC-3 and HL-60 cells were treated with different concentrations of G. olivalifolia fractions and extract for $48 \mathrm{~h}$ in triplicate. Cell viability was determined by MTT assay and indicated in percentage of cell viability of tree independent assays 


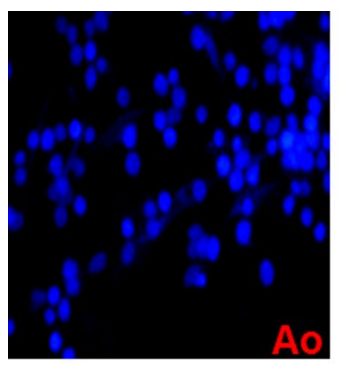

Ctrl

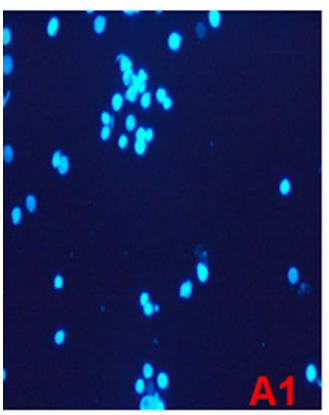

Campto

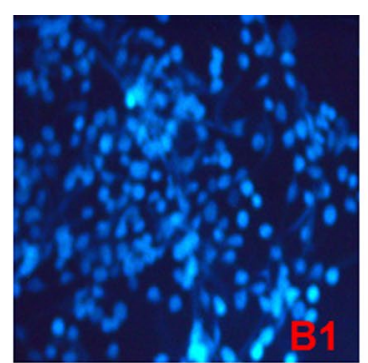

$\mathrm{B} 1 / 5 \mu \mathrm{g} / \mathrm{mL}$

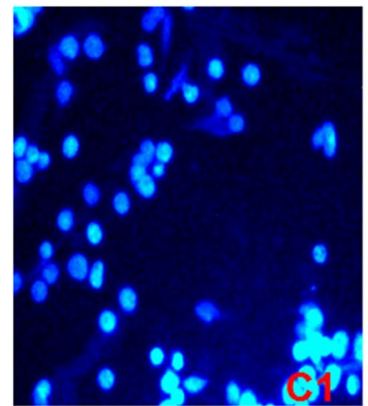

$\mathrm{C} 1 / 5 \mu \mathrm{g} / \mathrm{mL}$

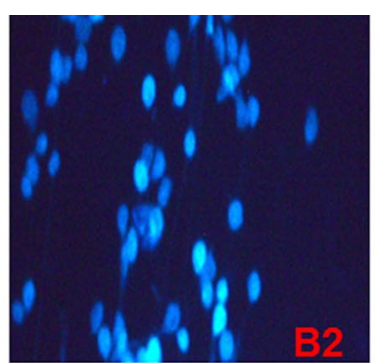

$\mathrm{B} 2 / 10 \mu \mathrm{g} / \mathrm{mL}$

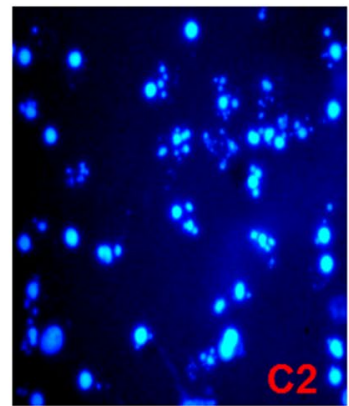

$\mathrm{C} 2 / 10 \mu \mathrm{g} / \mathrm{mL}$

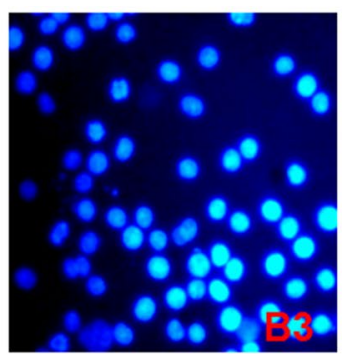

$\mathrm{B} 3 / 20 \mu \mathrm{g} / \mathrm{mL}$

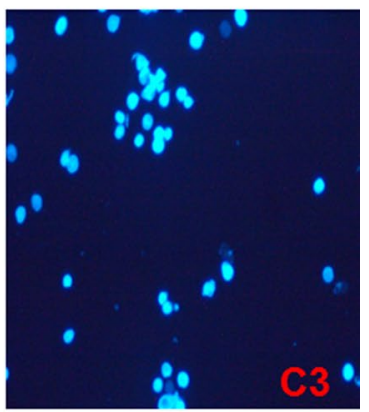

$\mathrm{C} 3 / 20 \mu \mathrm{g} / \mathrm{mL}$

Fig. 2 Effect of epi-garcinol and isogarcinol on nuclear morphological changes of HL-60 cells. After 24 h of treatment follow by staining with Hoechst 33258, the cells are incubated for 30 min and observed under fluorescence microscope. Olympus, Tokyo, Japan; magnification $\times 200$ ). (Ao): Control; (A1): Camptotecin (2 $\mu \mathrm{M})$; B: Epigarcinol (B1: $5 \mu \mathrm{g} / \mathrm{mL} ; \mathrm{B} 2: 10 \mu \mathrm{g} / \mathrm{mL} ; \mathrm{B} 3: 20 \mu \mathrm{g} / \mathrm{mL}) ; \mathrm{C}$ Isogarcinol (C1: $5 \mu \mathrm{g} / \mathrm{mL} ; \mathrm{C} 2: 10 \mu \mathrm{g} / \mathrm{mL} ; \mathrm{C} 3: 20 \mu \mathrm{g} / \mathrm{mL})$

\section{Mitochondrial membrane potential $(\Delta \Psi \mathrm{m})$}

The depletion of $\Delta \Psi \mathrm{m}$ is one of the earliest intracellular events that occur following the induction of apoptosis. To determine whether an early loss of $\Delta \Psi \mathrm{m}$ occurred during treatment with epigarcinol and isogarcinol in HL60cells, we performed $\Delta \Psi \mathrm{m}$ measurement using Rh-123 staining. In the untreated control cells, almost all cells were functionally active with high $\mathrm{Rh}-123$ fluorescence and the percentage of mitochondrial damage was still low (9.11 \%) (Fig. 4). The percentage of mitochondrial potential loss increased from 13.86 to $97.55 \%$ for B fraction and 12.55 to $98.27 \%$ isogarcinol when their concentration raised between 5 and $20 \mu \mathrm{g} / \mathrm{mL}$ (Fig. 4B). At $20 \mu \mathrm{g} /$ $\mathrm{mL}$, both epigarcinol and isogarcinol isolated from $G$. ovalifolia caused mitochondrial damage and hence the decrease of mitochondrial membrane potential up to $98 \%$ corresponding of 10 fold compare to the control (Fig. 4B). The loss of $\Delta \Psi \mathrm{m}$ is largely due to the opening of mitochondrial permeability transition pores (PTP), which conduit the leakage of cytochrome $\mathrm{c}$ and proapoptotic proteins from mitochondria to the cytosol.

\section{Effect of fractions of G. ovalifolia on cell cycle distribution} Quantitative analysis of DNA content with flow cytometry was conducted in order to determine whether the G. ovalifolia fractions was associated with the induction of cell cycle arrest and the distribution of cells in different phases of the cell cycle after $24 \mathrm{~h}$ exposure. After $24 \mathrm{~h}$ treatment with isogarcinol and epigarcinol, the HL-60 cells exhibited concentration dependent increase in hypo diploid sub-G $G_{1}$ DNA fraction $(<2 \mathrm{nDNA})$. The results revealed an increase in the sub-G1 apoptotic fraction in both molecules from $7.37 \%(5 \mu \mathrm{g} / \mathrm{mL})$ to $(88.89 \%) 20 \mu \mathrm{g} /$ $\mathrm{mL}$ (epigarcinol) and 18.8 to $93.11 \%$ (isogarcinol) when compared to the control (3.62 \%) (Fig. 5). The G1/Go and $\mathrm{G}_{2} / \mathrm{M}$ phases block in HL-60 cells decrease significantly as result of the treatment with $G$. ovalifolia fractions when compared to vehicle control (Fig. 5B). An increase in sub G1 fraction is usually associated with apoptosis as a result of DNA fragmentation [27]. Both molecules isogarcinol and epigarcinol isolated from G. ovalifolia showed an apoptosis at $10 \mu \mathrm{g} / \mathrm{mL}$ (49.23 and 81. $29 \%$, respectively for epigarcinol and isogarcinol compared to the control. In the experiment to measure the change in the cell cycle of HL-60 cells after epigarcinnol and isogarcinol $(10 \mu \mathrm{g} / \mathrm{mL})$, the $G_{2} / M$ population was found to be drastically shifted to the sub- $G_{1}$ population, while the significant reduction in the $G_{0} / G_{1}$ (Fig. 5C). Moreover, in the flow cytometry study, a sub- $G_{1}$ peak, which was considered as an indicator of cell apoptosis, was clearly observed after the treatment with epigarcinol and isogarcinol at the concentration higher than $(5 \mu \mathrm{g} / \mathrm{mL})$ (Fig. $5 \mathrm{~A}, \mathrm{~B})$. These results 

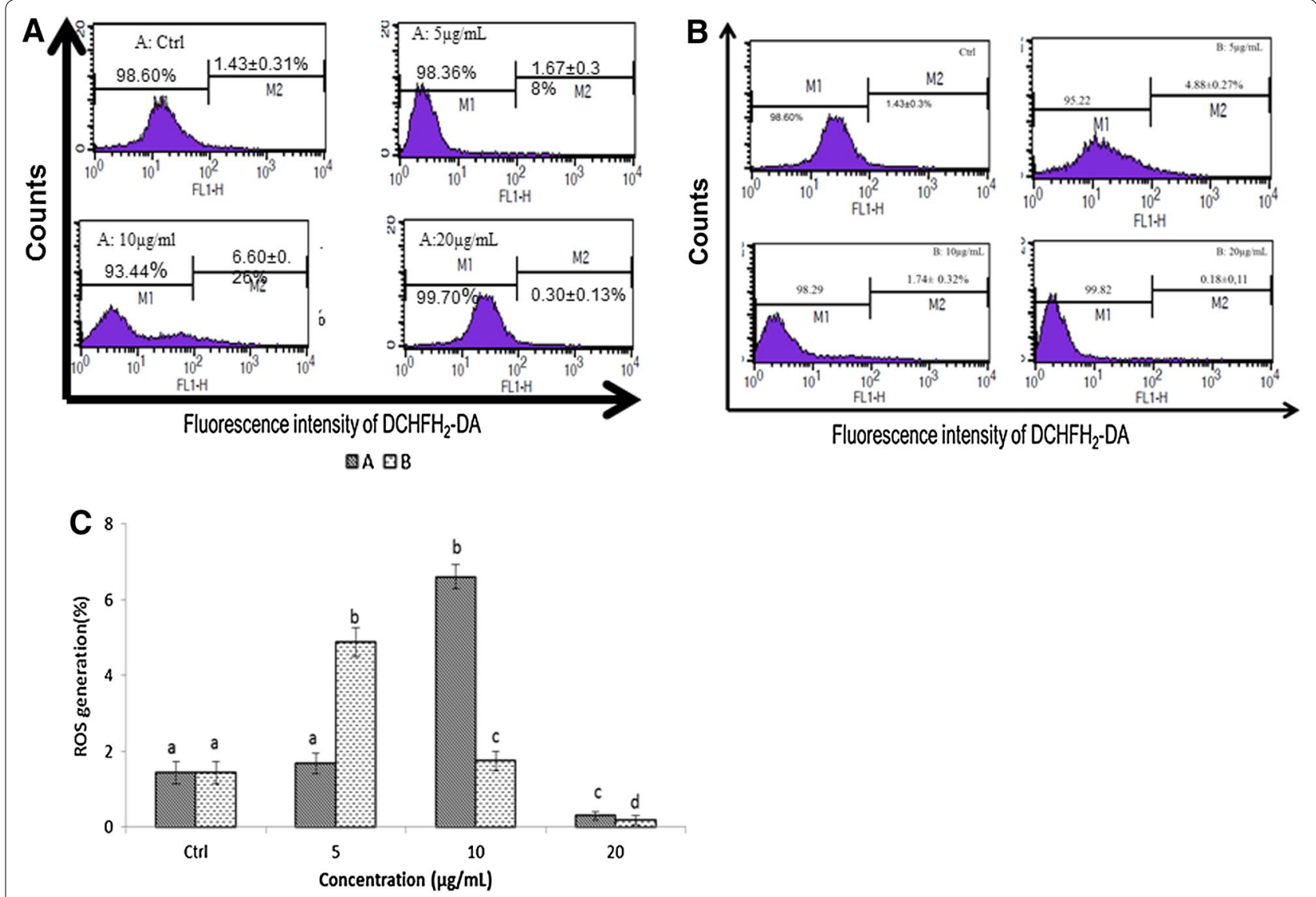

Fig. 3 Variation of ROS production of HL60 cells after treatment and analyzed by BD-FACS Caliber flow-cytometer; values are expressed as means \pm standard error $(n=3)$. Ctrl: Control; 5; 10; $20 \mu \mathrm{g} / \mathrm{mL}$. Values affected with different letters are significantly different $(p<0.05)$ from the control; $\mathbf{A}$ isopigarcinol; B epigarcinol; C distribution of ROS fluorescence of isogarcinol and epigarcinol

suggested that HL-60 cells treated with the two molecules underwent the typical apoptosis. All these indicated that epigarcinol and isogarcinol arrested HL-60 cells at the $\mathrm{G}_{2} / \mathrm{M}$ phase, and primarily stimulated the cells from the $\mathrm{G}_{2} / \mathrm{M}$ phase to the sub- $\mathrm{G}_{1}$ phase of apoptosis.

\section{Discussion}

Different types of cancer chemopreventive agents, including natural substances and pharmaceutical compounds, have been investigated for efficacy and efficiency in vitro and in vivo. The induction of apoptosis is known to be an efficient strategy for cancer therapy. Recently, extracts and molecules prepared from a variety of plants were demonstrated to possess the ability in triggering the apoptotic pathway [28]. Our study investigated the in vitro effects of epigarcinol and isogarcinol from $G$. ovalifolia extract on cell growth, morphology, cell cycle of HL-60 cancer cell line and the mechanism of apoptosis induced these two molecules.

As commonly known, naturally polyphenols such as garcinol and isogarcinol exhibited cytotoxic activity against HL-60 and PC-3 cells. The two molecules inhibited the proliferation of these two cells in a dose-dependent manner (Fig. 1) with the $\mathrm{IC}_{50}$ varying between 5 and $12 \mu \mathrm{g} / \mathrm{mL}$ (Table 1). Several studies demonstrated the growth inhibition properties of garcinol on different cells cancer including breast, lung, kidney, hepatocellular carcinoma, pancreatic [29-31]. The antiproliferative effects of isogarcinol was shown on HCT116 and CCRF-CEM cell lines [32].

It is also well known that in apoptosis, the earliest recognized morphological changes are compaction and segregation of the nuclear chromatin, with the result of chromatin margination and condensation of the cytoplasm. Our study demonstrated that epigarcinol and isogarcinol induced apoptosis of HL-60 cells as evidenced of alteration of cell morphology, DNA fragmentation, mitochondrial depolarization. After treatment of HL-60 cells with epigarcinol and isogarcinol for $24 \mathrm{~h}$, a representative population of apoptotic cells was also observed mainly at 10 and $20 \mu \mathrm{g} / \mathrm{mL}$, suggesting a rapid mechanism of apoptose induction that is gradually overwhelmed by the 


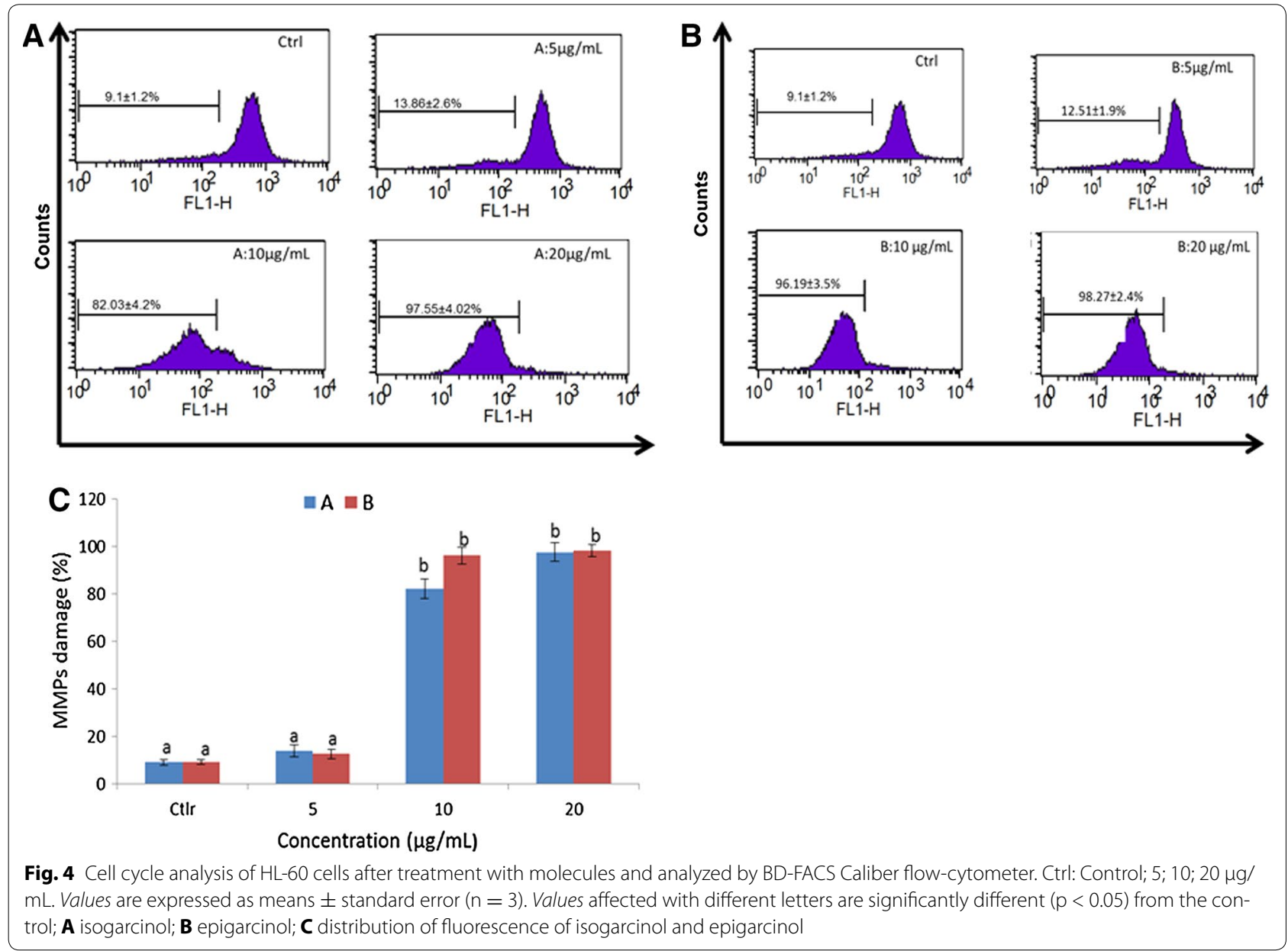

activation of apoptotic pathways. In the present study, the treated cells displayed significant apoptosis-related morphological alterations, such as apoptotic body formation and chromatin condensation. The effects of garcinol in tumor cells have been studied; its mechanism of action is elucidated for several cancer cells lines [29, 33]. The mechanistic cytotoxic activity of garcinol similar to isogarcinol which may include downregulation of MMP-9, IL-8, PGE-2, and VEGF, markers of angiogenesis and metastasis in pancreatic cancer cell lines, Panc 1 and BxPC3 and induction of ROS through death receptor, mitochondrial and modulating GADD153 [34, 35].

ROS are involved in several different cellular processes ranging from apoptosis and necrosis to cell proliferation and carcinogenesis [36, 37], and the mitochondrion is a very important site of ROS production. Mitochondria are a source of ROS during apoptosis and reduced mitochondrial membrane potential leads to increase generation of ROS and apoptosis [38] ROS can induce and maintain the collapse of $\Delta \psi \mathrm{m}$, leading to cellular damage through the oxidation of lipids and proteins, resulting in apoptotic cell death [39]. Controversially, other studies estimated that both mitochondria and ROS production seem to be involved in necrotic cell death $[37,40]$. Whether the treated cells undergo apoptosis or necrosis depend on the concentration of ROS and the time of exposure to ROS [41]. Our results showed that epigarcinol and isogarcinol inhibited growth of HL-60 cells and induced apoptosis and ROS generation not in a dose-dependent manner. Because cell cycle and apoptosis are involved in the regulation of cell growth, they were detected with a flow cytometer $24 \mathrm{~h}$ after the treatment with epigarcinol and isogarcinol in our study. The results showed that after treated with the two molecules for $24 \mathrm{~h}$, the cells arrested at $G_{0} / G_{1}$ and $G_{2} / M$ phases decreased respectively and the increase of sub- $G_{1}$, suggesting that these molecules induce significant apoptosis.

Even though apoptosis involves both intrinsic and extrinsic pathways, tumors arise more frequently through the intrinsic pathway than the extrinsic pathway because 


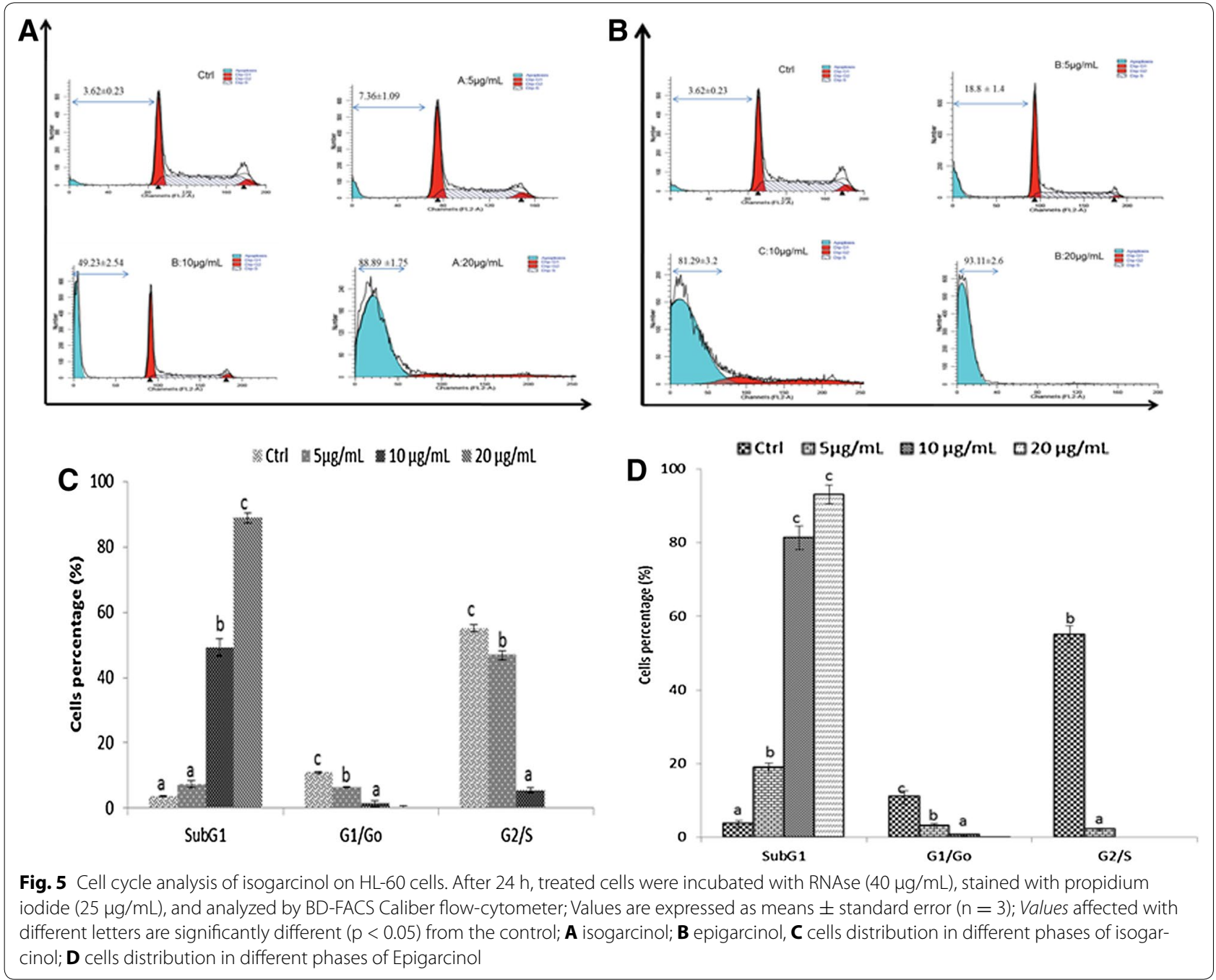

of its sensitivity [42]. The main intrinsic pathway is characterized by mitochondrial dysfunction, with the release of cytochrome c. Since mitochondria have the ability to activate the cellular apoptotic program directly, they are considered the major cellular component in the intrinsic way of apoptosis [43]. The mitochondria play an important role in the progression of apoptosis. In the study, the decrease of $\Delta \psi \mathrm{m}$ was enhanced by increasing concentration of epigarcinol and isogarcinol. These results suggest that the two molecules indeed induced apoptosis in HL-60 cells A decrease in $\Delta \psi \mathrm{m}$ disrupts the outer mitochondrial membrane and causes the opening of the permeability transition pore, followed by the lease of pro-apoptotic factors, and resulting in subsequent apoptosis [44-47]. Other studies demonstrated the inhibition of CBP/p300 acetyltransferase activity by garcinol and several multiple biological effects in cancer cells, including the activation of DNA damage signaling and the induction of chromatin regulators such as TIP60 and SUV420 [47].

\section{Conclusion}

The bioassay-guided approach to the processing of $G$. ovalifolia led to the isolation and purification of epigarcinol and isogarcinol. We demonstrated that epigarcinol and isogarcinol from G. ovalifolia can inhibit the proliferation of HL-60 cells and this inhibitory effect was related to $\mathrm{G} 2 / \mathrm{M}$ phase arrest and apoptosis the mitochondrial pathway. The cytotoxic results obtained from our work represent new insight into the traditional use of G. ovalifolia as an anticancer plant. Epigarcinol and isogarcinol may thus warrant further in vivo studies so as to develop it as a successful natural compound that could be used for the treatment in leukemia after determine the entire mechanism of its cytotoxicity. 


\section{Authors' contributions}

PCA design, perform the study and write the manuscript; AP and YE carried out the purification of molecule, AKS provided all the reagent and chemical. All authors read and approved the final manuscript.

\section{Author details}

${ }^{1}$ Department of Physiological Sciences and Biochemistry, Faculty of Medicine and Biomedical Sciences, University of Yaoundé I, PO Box 1364, Yaoundé, Cameroon. ${ }^{2}$ Cancer Pharmacology Division, Indian Institute of Integrative Medicine, 180001, Canal Road, Jammu, India. ${ }^{3}$ Department of Chemistry, Faculty of Sciences, University of Yaoundé I, PO Box 812, Yaounde, Cameroon.

\section{Acknowledgements}

The authors wish to thank the Federation of Indian Chambers of Commerce and Industry (FICCI), who provided scholarships to Dr. PIEME C.A. through CV Raman program to conduct this research in the Indian Institute of Integrative Medicine (CSIR).

\section{Competing interests}

The author(s) declared no potential conflicts of interest with respect to the research authorship and/or publication of this article.

Received: 18 July 2014 Accepted: 19 October 2015

Published online: 23 November 2015

\section{References}

1. Ferlay J, Soerjomataram I, Ervik M, Dikshit R, Eser S, Mathers C, Rebelo M, Parkin DM, Forman D, Bray F. Cancer Incidence and Mortality Worldwide: IARC Cancer Base 2013 No. 11 [Internet]. Lyon, France: International Agency for Research on Cancer. Available from http://globocan.iarc.fr.

2. Xia D, Fang-Shi Z, Min L, Si-Guo G. Induction of apoptosis in human hepatoma SMMC-7721 cells by solamargine from Solanum nigrum L. J Ethnopharmacol. 2012;139:599-600.

3. Schwartsmann G, Ratain MJ, Cragg GM, Wong JE, Saijo N, Parkinson DR, Fujiwara Y, Pazdur R, Newman DJ, Dagher R, Di Leone L. Anticancer drug discovery and development throughout the world. J Clin Oncol. 2002;20(18):47S-59S.

4. Tan ML, Sulaiman SF, Najimuddin N, Samian MR. Tengku Muhammad TS: methanolic extract of Pereskia bleo (Kunth) DC. (Cactaceae) induces apoptosis in breast carcinoma, T47-D cell line. J Ethnopharmacol. 2005;96:287-94.

5. Li XK, Motwani M, Tong W, Bornmann W, Schwartz GK. Huanglian a Chinese herbal extract, inhibits cell growth by suppressing the expression of cyclin B1 and inhibiting CDC2 kinase activity in human cancer cells. Mol Pharmacol. 2000;58:1287-93.

6. Vickers A. Botanical medicines for the treatment of cancer: rationale, overview of current data, and methodological considerations for phase I and II trials. Cancer Invest. 2002;20:1069-79.

7. Orallo F. Comparative studies of the antioxidant effects of cis- and transresveratrol. Current Med Chem. 2006;13(1):87-98.

8. Nigro P, Bloise E, Turco MC, Skhirtladze A, Montoro P, Pizza C, Piacente S, Belisario MA. Antiproliferative and pro-apoptotic activity of novel phenolic derivatives of resveratrol. Life Sci. 2007;81(11):873-83.

9. Magadula JJ. Bioactive benzophenone from stem bark and fruit hull from Garcina Senseii Verdc. Int J Phytochem Pharmacol. 2012;2(1):16-20.

10. Gustafson KR, Blunt JW, Munro MHG, Fuller RW, McKee TC, Cardellina IIJH, McMahon JB, Cragg GM, Boyd MR. The guttiferones, HIY-inhibitory Benzophenones from Svmuhonia alobulifera, w livinastonei, Garcinia ovalifolia and Clusia rosea. Telrahedron. 1992;46:10093-102.

11. Magadula JJ, Suleimani HO. Cytotoxic and anti-HIV activities of some Tanzanian Garcinia species. Tanz J Health Res. 2010;12(2):1-7.

12. Lannang AM, Noudou BS, Sewald N. Ovalifolone A and B: new friedelane derivatives from Garcinia ovalifolia. Phytochem Lett. 2013;6:157-61.

13. Magadula JJ. Bioactive mammea type coumarins and benzophenone from two Clusiaceae plants. J Pharmaceut Sci Innov. 2012;1(5):31-3.

14. Louh NG, Meli LA, Mbazoa DC, Tangmouo JG, Komguem J, Castillo J, Mofo NF, Naz Q, Lontsi D, lqbal MC, Sondengam BL. Polyanxanthone A, B and $C$, three xanthones from the wood trunk of Garcinia polyantha Oliv. Phytochem. 2008;69:1013-7.
15. Ngouamegne ET, Fongang RS, Ngouela S, Boyom FF, Rohmer M, Tsamo E, Gut J, Rosenthal P. Endodesmiadiol, a friedelane triterpenoid, and other antiplasmodial compounds from Endodesmia calophylloides. J Chem Pharm Bul. 2008;56:374-7.

16. Meli Lannang A, Louh NG, Lontsi D, Specht S, Sarite SR, Florke U, Hussain $\mathrm{H}$, Hoerauf A, Krohn K. Antimalarial compounds from the root bark of Garcinia polyantha Oliv. J Antibiotic 2008;61:518-523.

17. Biloa MB, Ndjoko IK, Hertlein AB, Lannang AM, Nkengfack EA, Wolfender $J$, Hostettmann K, Bringmann G. Preussianone, a New Flavanone-Chromone Biflavonoid from Garcinia preussii Engl. Molecules. 2012;17:611425. doi:10.3390/molecules17056114.

18. Tchakam PD, Lunga KP, Kowa KT, Lonfouo NAH, Wabo KH, Tapondjou AL, Tane P, Kuiate JR: Antimicrobial and antioxidant activities of the extracts and compounds from the leaves of Psorospermum aurantiacum Engl. and Hypericum lanceolatum Lam. BMC Compl Altern Med 2012;12(136):1-8.

19. Kim JJ, Chung IM, Jung JC, Kim MY, Moon HI. In vivo antiplasmodial activity of 11(13)-dehydroivaxillin from Carpesium ceruum. J Enzym Inhib Med Chem. 2009;24:247-50.

20. Marti G, Eparvier V, Moretti C, Prado S, Grellier P, Hue N, Thoison O, Delpech B, Guéritte F, Litaudon M. Antiplasmodial benzophenone derivatives from the root barks of Symphonia globulifera (Clusiaceae). Phytochem. 2010;71:964-74.

21. Vatcharin R, Wanpen N, Yaowapa S, Souwalak P. An Antibacterial Biphenyl Derivative from Garcinia bancana MIQ. Chem Pharm Bull. 2005;53(3):342-3.

22. Noungoue DT, Chaabi M, Ngouela S, Antheaume C, Boyom FF, Gut J, Rosenthal PJ, Lobstein A, Tsamo E. Antimalarial compounds from the stem bark of Vismia laurentii. Z Naturforsch (C). 2009;64:210-4.

23. Bero J, Quetin-Leclercq J. Natural products published in 2009 from plants traditionally used to treat malaria. Planta Med. 2011;77:631-40.

24. Cen J, Shi M, Yang Y, Fu Y, Zhou H, Wang M, Su Z, Qun W. Isogarcinol is a new immunosuppressant. PLoS ONE. 2013;8(6):e66503. doi:10.1371/journal.pone.0066503.

25. Kirk RG, Blunt JW, Murray HGM, Fuller RW, McKee TC, Cardellina IIJH, McMahon JB, Cragg GM, Boyd MR. The guttiferones, HIY-inhibitory Benzophenones from Svmuhonia alobulifera, w livinastonei, Garcinia ovalifolia and Clusia rosea. Tetrahedron. 1992;48(46):10093-102. doi:10.1016/ S0040-4020(01)89039-6.

26. Bhushan S, Kakkar V, Pal HC, Guru SK, Kumar A, Mondhe DM, Sharma PR, Taneja SC, Kaur IP, Singh J, Saxena AK. Enhanced anticancer potential of encapsulated solid lipid nanoparticles of TPD: a novel triterpenediol from Boswellia serrata. Mol Pharmarcol. 2013;10:225-35.

27. Standera A, Marais S, Stivaktas V, Vorster C, Albrecht C, Lottering ML, Joubert AM. In vitro effects of Sutherlandia frutescens water extracts on cell numbers, morphology, cell cycle progression and cell death in a tumorigenic and a non-tumorigenic epithelial breast cell line. J Ethnopharmacol. 2009;124:45-60.

28. Shu-Jing W, Lean-Teik N, Ching-Hsein C, Doung-Liang L, Shyh-Shyan W, Chun-Ching L. Antihepatoma activity of Physalis angulata and P. peruviana extracts and their effects on apoptosis in human Hep G2 cells. Life Sci. 2004;74(16):2061-73.

29. Prasad S, Ravindran J, Sung B, Pandey MK, Aggarwal BB. Garcinol potentiates TRAIL-induced apoptosis through modulation of death receptors and antiapoptotic proteins. Mol Cancer Therap. 2010;9(4):856-68.

30. Subhash P, Aamir A, Nikhil O. Fazlul HS. Emerging role of Garcinol, the antioxidant chalcone from Garcinia indica Choisy and its synthetic analogs. J Hematol Oncol. 2009;2(38):1-13.

31. Nadia S, Gupta SV: Potential Role of Garcinol as an Anticancer Agent. J Oncol 2012 ID 647206. doi:10.1155/2012/647206.

32. Kuete V, Tchakam PD, Wiench B, Ngameni B, Wabo HK, Tala M, Moungang ML, Ngadjui BT, Murayama T, Efferth T. Cytotoxicity and modes of action of four naturally occuring benzophenones: 2,2',5,6' tetrahydroxybenzophenone, guttiferone $\mathrm{E}$, isogarcinol and isoxanthochymol. Phytomed. 2013;20(6):528-36.

33. Ahmad A, Sarkar SH, Bitar B, Ali S, Aboukameel A, Sethi S, Li Y, Bao B, Kong D, Banerjee S, Padhye SB, Sarkar FH. Garcinol Regulates EMT and Wnt Signaling Pathways In Vitro and In Vivo, Leading to Anticancer Activity against Breast Cancer Cells. Mol Cancer Therap. 2012;11(10):2193-201.

34. Ohnish H, Asamoto M, Tujimura K, Hokaiwado N, Takahashi S, Ogawa K, Kuribayashi M, Ogiso T, Okuyama H, Shirai T. Inhibition of cell proliferation by nobiletin, a dietary phytochemical, associated with apoptosis and characteristic gene expression, but lack of effect on early rat hepatocarcinogenesis in vivo. Cancer Sci. 2004;95(12):936-42. 
35. Cheng AC, Tsai ML, Liu CM, Lee MF, Nagabhushanam K, Ho CT, Pan $\mathrm{MH}$. Garcinol inhibits cell growth in hepatocellular carcinoma Hep3B cells through induction of ROS-dependent apoptosis. Food Funct. 2010;1(3):301-7.

36. Matés JM, Segura JA, Alonso FJ, Márquez J. Intracellular redox status and oxidative stress: implications for cell proliferation, apoptosis, and carcinogenesis. Arch Toxicol. 2008;82:273-99.

37. Marinho-Filho JDB, Bezerrab DP, Araújo AJ, Montenegro RC, Pessoa C, Diniz JC, Viana FA, Pesso ODL, Silveira ER, De Moraes MO, Costa-Lotufo LV. Oxidative stress induction by (+)-cordiaquinone J triggers both mitochondria-dependent apoptosis and necrosis in leukemia cells. Chem Biol Interact. 2010;183(3):369-79.

38. Pieme Constant Anatole, Santoh Kumar G, Ngamegni B., Ngogang J, Shashi B, Tetsuya M, Ajit Kumar S. Ethyl acetate fraction of Garcina epunctata inducesapoptosis in human promyelocytic cells $(\mathrm{HL}-60)$ through the ROS generation and G0/G1 cell cycle arrest: A bioassay-guided approach. Environ Toxicol Pharmacol. 2013;865-874.

39. Castello-Branco MVS, Tavares JF, Silva MS, Barbosa-Filho JM, Anazetti MC, Frungillo L, Haun M, Melo-Diniz MFF, Melo PS. Xylodiol from Xylopia langsdorfiana induces apoptosis in HL60 cells. Revista Brasileira de Farmacognosia Braz J Pharmacog. 2011;21(6):1035-42.

40. Hillard EA, Abreu FC, Ferreira CCM, Jaouen G, Goulart MOF, Amatore C. Electrochemical parameters and techniques in drug development, with an emphasis on quinone and related compounds. Chemical Comm 2008;2612-2628.
41. Bartosz G. Reactive oxygen species: destroyers or messengers? Bioch Pharmacol. 2009;77:1303-5.

42. Mohan S, Abdelwahab SI, Kamalidehghan B, Syam S, May KS, Harmal NSM, Shafifiyaz N, Hadi AHA, Hashim NM, Rahmani M. Involvement of NF-kB and BCl2/Bax signaling pathways in the apoptosis of MCF7 cells induced by axanthone compound Pyranocycloartobiloxanthone A. Phytomed. 2012;19:1007-15.

43. Ismail AA, Ahmad BA, Mohd AS, Rasedee A, Suvitha S, Behnam K, Mohamed Y, Manal-Mohamed ET, Siddig IA, Hapipah MA, Syam M. Dentatin isolated from Clausena excavata induces apoptosis in MCF-7cells through the intrinsic pathway with involvement of NF-kB signaling and G0/G1 cell cycle arrest: a bioassay-guided approach. J Ethnopharmacol. 2013;145:343-54

44. Zimmermann KC, Green DR. How cells die: apoptosis pathways. J Allergy Clin. Immunol. 2001;108:S99-103.

45. Bouchier-Hayes L, Lartigue L, Newmeyer DD. Mitochondria: pharmacological manipulation of cell death. J Clin Invest. 2005;115:2640-7.

46. Hong-xia L, Pan W, Quanhong L, Xiaoxia C, Yuetao Z, Yaping X. Cell cycle arrest and cell apoptosis induced by Equisetum hyemale extract in murine leukemia L1210 cells. J Ethnopharmacol. 2012;144:322-7.

47. Collins HM, Abdelghany MK, Messmer M, Baigong Y, Deeves SE, Kindle KB, Kempegowda M, Akhmed A, Winkler GS, Kundu TK, Heery DM. Differential effects of garcinol and curcumin on histone and p53 modifications in tumour cells. BMC Cancer 2013;13(37): doi:10.1186/1471-2407-13-37.

\section{Submit your next manuscript to BioMed Central and take full advantage of:}

- Convenient online submission

- Thorough peer review

- No space constraints or color figure charges

- Immediate publication on acceptance

- Inclusion in PubMed, CAS, Scopus and Google Scholar

- Research which is freely available for redistribution

Submit your manuscript at

www.biomedcentral.com/submit

C BioMed Central 